\title{
Effect of FOLFOX6 chemotherapy on serum VEGF expression in advanced colorectal cancer patients
}

\author{
(D) Kong Ying ${ }^{1}$ \\ (iD) Yang Chong ${ }^{1}$ \\ (iD) Wang Wei \\ (iD) Dong Bing ${ }^{1}$ \\ (iD) Su Yanyan ${ }^{1}$ \\ (iD) YiXuefeng ${ }^{1}$ \\ (D) Wang Wei ${ }^{1}$ \\ (iD) LiKe
}

1. Hangzhou Red Cross Hospital, Department of General Surgery, Hangzhou, Zhejiang, 310003, China

\section{SUMMARY}

OBJECTIVE: To explore the effect of FOLFOX6 chemotherapy on serum vascular endothelial growth factor (VEGF) expression in advanced colorectal cancer patients.

METHODS: A retrospective analysis of 81 patients with advanced colorectal cancer who visited our hospital from March 2014 to February 2016 was performed. All the patients were treated with FOLFOX6 chemotherapy. On day 1, patients received oxaliplatin $100 \mathrm{mg} /$ $\mathrm{m} 2 \mathrm{ivgtt}(2 \mathrm{~h}$ ), calcium folinate $200 \mathrm{mg} / \mathrm{m} 2 \mathrm{ivgtt}$ (2h), 5 fluorouracil $400 \mathrm{mg} / \mathrm{m2} \mathrm{iv}$ bolus and 5 fluorouracil $2500 \mathrm{mg} / \mathrm{m} 2 \mathrm{ivgtt}$ (5h). The treatment course was 2 weeks, and 4 treatment courses were required. The changes in the levels of VEGF and CRP and quality of life before and after 4 courses of chemotherapy were observed and therapeutic effects and adverse reactions after chemotherapy were evaluated.

RESULTS: After treatment, the total efficiency of chemotherapy was 82.72\% (67/81) with 24 cases in complete remission, 25 cases in partial response, 18 cases in stable disease and 14 cases in progressive disease. The levels of CRP and VEGF after the treatment were significantly lower than those before treatment $(5.69 \pm 0.77) \mathrm{mg} / \mathrm{L}$ vs. $(7.99 \pm 7.36) \mathrm{mg} / \mathrm{L} ;(443.26 \pm 21.55) \mathrm{pg} / \mathrm{mL} \mathrm{vs}$. $(542.83 \pm 20.44) \mathrm{pg} / \mathrm{mL}]$ $(P<0.05)$. The KPS grade after treatment was significantly higher than that before treatment (57.84 \pm 4.6$)$ point vs. (50.99 \pm 3.73$)$ point] $(P<0.05)$. Among them, 3 cases developed a rash, 5 cases experienced hair loss, and 9 cases developed nausea and vomiting.

CONCLUSION: FOLFOX6 chemotherapy can decrease serum VEGF expression in patients with advanced colorectal cancer and enhance the curative effect with high safety, which is good for the improvement of patients' survival.

KEYWORDS: Colorectal neoplasms. Vascular endothelial growth factor A. Drug therapy.

\section{INTRODUCTION}

Among various malignant tumors, colorectal cancer is a common one whose morbidity and mortality are at the forefront with a rising trend each year ${ }^{1}$. In China, approximately 400,000 people are diagnosed with colorectal cancer every year ${ }^{2}$. Typi- cal symptoms of early-stage colorectal cancers are absent and only appear as indigestion, discomfort, fecal occult blood, etc. With the further development of cancer, more clinical symptoms appear, mainly as an abdominal mass, blood in the stool, 
abdominal pain, change in bowel habits, bowel obstruction with and without weight loss, fever, anemia, and other systemic symptoms. The affected organs can change because of infiltration and metastasis of the tumor ${ }^{3-5}$.

In the treatment of colorectal cancer, excision is the most effective method. However, in many cases, when patients are diagnosed as colorectal cancer, it has already developed to middle and advanced-stage and chemotherapy becomes a major treatment method at this time ${ }^{6}$. The key is how to predict the effect of chemotherapy and take timely and effective treatment measures. In the research for colorectal cancer treatment, the relationship between expression of vascular endothelial growth factor (VEGF), C-reactive protein (CRP), clinical cancer behavior, and the prognosis is deemed as a critical research category ${ }^{7,8}$. To explore the effectiveness of FOLFOX6 chemotherapy, this study analyzes its effects on serum vascular endothelial growth factor (VEGF) expression in advanced colorectal cancer patients. These cases are reported as below.

\section{MATERIAL, SUBJECT, AND METHOD}

\section{Study design}

This study was mainly designed following the retrospective analysis protocol.

\section{Case selection}

A retrospective analysis of 81 patients with advanced colorectal cancer who visited our hospital from March 2014 to February 2016 was performed. Although there is no clear definition of advanced colorectal cancer, it is usually distinguished from early-stage cancer. Generally, both locally advanced cancer and metastatic cancer are included. Here, we enrolled all the clinical stages T3 or T4 or node-positive colorectal cancer, with or without metastasis, as advanced colorectal cancer.

\section{Inclusion criteria4:}

(1) Patients whose diseases were confirmed by pathological examination. (2) Patients who were conscious and had the ability of healthy communication and exchange and had no history of mental illness. (3) Patients who were in good compliance and could cooperate with the medical staff to complete the study.

\section{Exclusion criteria:}

(1) Patients who had received prior radiotherapy and chemotherapy, surgery and other particular treatment methods before this study. (2) Patients whose survival time was less than 3 months. (3) Patients with contraindication to chemotherapy. (4) Previous history of cancer

\section{Drug and instrument}

Oxaliplatin Injection, specification: 100ml: 100mg, manufacturer: Jiangsu Hengrui Medicine Co., Ltd, batch No.:20131103; Calcium Folinate, specification: 10ml: 100mg, manufacturer: Jiangsu Hengrui Medicine Co., Ltd, batch No.:20131221; 5fluorouracil, manufacturer: Tianjin Kingyork Co. Ltd, specification: $10 \mathrm{ml}$ : $250 \mathrm{mg}{ }^{*} 5$ vials, batch No.:20140103.

Room temperature centrifuge: SICMA 1-13, Sigma, Germany; Refrigerator: LC-128, Haier, Qingdao; Automatic biochemical analyzer: ADVID 1800, Siemens, Germany; ELISA Kit for Vascular Endothelial Growth Factor (VEGF), Shenzhen Jingmei Biotech company; CRP ELISA Kit, Roche, the United States.

\section{Grouping and treatment}

All the patients were treated with FOLFOX6 chemotherapy. On day 1, patients received oxaliplatin $100 \mathrm{mg} / \mathrm{m} 2$ iv gtt (2h), Calcium Folinate $200 \mathrm{mg} /$ $\mathrm{m} 2$ iv gtt (2h), 5 fluorouracil $400 \mathrm{mg} / \mathrm{m} 2$ iv bolus and 5fluorouracil $2500 \mathrm{mg} / \mathrm{m} 2 \mathrm{iv}$ gtt (5h). The treatment course was 2 weeks, and 4 treatment courses were required.

Observation parameters and efficacy evaluation criteria

The changes in the levels of VEGF and CRP before and after 4 courses of chemotherapy were observed. A $5 \mathrm{~mL}$ sample of the fasting venous blood respectively before and after 4 courses of treatment was collected and mixed. The blood was centrifuged for $10 \mathrm{~min}$ at $3000 \mathrm{r} / \mathrm{min}$, and the serum was collected and preserved in the refrigerator at $-50^{\circ} \mathrm{C}$. ELISA was adopted to detect VEGF levels, and immune turbidimetry was used to measure CRP levels. The survival quality points before and after treatment were analyzed using Karnofsky (KPS) with a total point of 100 . The evaluation criteria are as follows: death represents 0 points; impending death represents 10 scores; seriously ill represents 20 scores; could not care for self 
seriously represents 30 scores; could not care for self and needs special help and care represents 40 scores; often needs someone's help represents 50 scores; mostly cares for self but occasionally needs help represents 60 scores; lives independently but has difficulty maintaining a normal life and work represents 70 points; barely able to carry out normal activities with some signs or symptoms represents 80 scores; carries out normal activities with some mild signs and symptoms represents 90 points; normal without signs and symptoms represents 100 points. The lower the score, the worse the quality of life. The adverse reactions after treatment were observed.

The baseline characteristics were observed before the therapy. Moreover, the responses to chemotherapy were evaluated after 4 courses. A therapeutic evaluation was conducted according to RECIST criteria9, including complete remission(CP), partial response(PR), stable disease (SD) and progressive disease(PD). The disease control rates $(\mathrm{DCR})=\mathrm{CR}+\mathrm{PR}+\mathrm{SD}$, the objective response rate $(\mathrm{ORR})=\mathrm{CR}+\mathrm{PR}$.

\section{Statistical analyses}

All the data were analyzed using software package SPSS 18.0. GRP, VEGF and other quantitative data were expressed as the average \pm standard deviation $(\mathrm{x} \pm \mathrm{s})$, and $\mathrm{t}$-test was used. The difference was regarded as statistically significant when $\mathrm{P}<0.05$.

\section{RESULTS}

\section{General information}

Among 81 patients with advanced colorectal cancer, there were 48 males and 33 females aged from 41-78 years with an average of $(61.32 \pm 2.32)$ years. Forty-six cases had colon cancer, and 35 cases had rectal cancer. Thirty-one cases were poorly differentiated adenocarcinoma, 20 cases were moderately differentiated adenocarcinoma, and 30 cases were highly differentiated adenocarcinoma. Twenty-one cases had hepatic metastases, 12 cases had pulmonary metastasis, 17 cases had lymphatic metastasis, 15 cases had bone metastases, and 16 cases were within the pelvic recurrence. See Table 1.

\section{Recent clinical efficacy analysis}

After treatment, 24 cases were in complete remis- sion, 25 were in partial response, 18 were in stable disease, and 14 were in progressive disease; the total efficacy was $82.72 \%(67 / 81)$. See Table 2 .

CRP and VEGF level comparison before and after treatment

CRP and VEGF levels were significantly lower after treatment than before. The difference was statistically significant $(\mathrm{P}<0.05)$. See Table 3.

\section{KPS grade comparison before and after treat-} ment

KPS grade after treatment $(57.84 \pm 4.6)$ was significantly higher than before (50.99 \pm 3.73$)$. The difference was statistically significant $(\mathrm{P}<0.05)$. See Table 4 .

\section{Safety assessment}

After treatment, all the patients had different degrees of adverse reactions, which mainly appeared as vomiting, hair loss, and rashes. Among the adverse reactions, 3 cases developed a rash, 5 experienced hair loss, and 9 developed nausea and vomiting. See Table 5.

\section{DISCUSSION}

Colorectal cancer is a common malignant tumor, and 5-year survival rate after surgery is generally about $50 \%$. The factor that leads to failure is largely related to metastasis and recurrence. The main metastasis is in the lymph, and VEGF plays a critical role in the lymphatic metastasis and blood stream ${ }^{10-12}$. A study by Xin et al. ${ }^{13}$, among others, have shown that angiogenesis can promote tumor growth and metastasis. VEGF, a substantial factor in stimulating blood vessel formation, was inseparable from tumor growth, metastasis, invasion and angiogenesis ${ }^{14}$. VEGF was mainly for promoting lymphatic endothelial cell growth and strengthening vascular permeability which was conducive to the formation of new blood vessels and proliferation of endothelial cells. It not only supplied the nutrients needed for tumor growth and removed metabolic products but also supplied the route for the corresponding spread of tumor cells. A high level of VEGF in serum reminds that the tumor is widely infiltrated, at an advanced stage, or associated with distant lesion metastasis. Observing the level of serum VEGF can help predict tumor growth, metastasis, and invasion ${ }^{15,16}$. In addition, a high ex- 
TABLE 1: GENERAL INFORMATION

\begin{tabular}{l|l}
\hline Item & $48 / 33$ \\
\hline Sex(male/female) & $61.32 \pm 2.32$ \\
\hline Age(year) & \\
\hline Pathologic types & $46(56.79)$ \\
\hline Colon cancer & $35(43.21)$ \\
\hline Colorectal cancer & \\
\hline Degree of differentiation & $31(38.27)$ \\
\hline Poorly differentiated adenocarcinoma & $20(24.69)$ \\
\hline Moderately differentiated adenocarcinoma differentiated adenocarcinoma & $30(37.04)$ \\
\hline Transfer case & \\
\hline Hepatic metastases & $21(25.93)$ \\
\hline Pulmonary metastasis & $12(14.81)$ \\
\hline Lymphatic metastasis & $17(20.99)$ \\
\hline Bone metastasis & $15(18.52)$ \\
\hline Within the pelvic recurrence & $16(19.75)$ \\
\hline
\end{tabular}

TABLE 2: RECENT CLINICAL EFFICACY ANALYSIS (N, \%)

\begin{tabular}{l|l|l|l|l|l|l} 
Item & $\mathrm{CR}$ & $\mathrm{PR}$ & $\mathrm{SD}$ & $\mathrm{PD}$ & $\mathrm{ORR}$ & $\mathrm{DCR}$ \\
\hline & 24 & 25 & 18 & 14 & 49 & 67 \\
& $(29.63)$ & $(30.86)$ & $(22.22)$ & $(17.28)$ & $(60.49)$ & $(82.72)$ \\
\hline
\end{tabular}

CR: Complete Remission; PR: Partial Response; SD: Stable Disease; PD: Progressive Disease;

TABLE 3: CRP AND VEGF LEVEL COMPARISON BEFORE AND AFTER TREATMENT $(\bar{\chi} \pm S)$

\begin{tabular}{l|l|l} 
Time & CRP $(\mathrm{mg} / \mathrm{L})$ & VEGF $(\mathrm{pg} / \mathrm{mL})$ \\
\hline Before treatment & $7.99 \pm 1.36$ & $542.83 \pm 20.44$ \\
\hline After treatment & $5.69 \pm 0.77^{\star}$ & $443.26 \pm 21.55^{\star}$ \\
\hline
\end{tabular}

Compared with before treatment, ${ }^{*} P<0.05$

TABLE 4: KPS GRADE COMPARISON BEFORE AND AFTER TREATMENT $(\bar{\chi} \pm S)$

\begin{tabular}{l|l} 
Time & KPS grade(point) \\
\hline Before treatment & $50.99 \pm 3.73$ \\
\hline After treatment & $57.84 \pm 4.62^{*}$ \\
\hline Compared with before treatment, ${ }^{*} \mathrm{P}<0.05$
\end{tabular}

TABLE 5: ADVERSE REACTIONS ANALYSIS

\begin{tabular}{l|l|l|l|l|} 
Item & Rash & Hair loss & $\begin{array}{l}\text { Nausea and } \\
\text { vomiting }\end{array}$ & $\begin{array}{l}\text { Overall adverse } \\
\text { reactions }\end{array}$ \\
\hline & $3(3.70)$ & $5(6.17)$ & $9(11.11)$ & $17(20.99)$ \\
\hline
\end{tabular}

pression of VEGF is closely correlated with tumor recurrence and prognosis.

CRP is a typical acute phase protein which appears initially in acute inflammation patients and increases in cancer patients. Wenbo et al. ${ }^{17}$ and related scholars propose that persistent in- flammation caused by tissue damage or chronic inflammation transfers the tumor cells or pro-inflammatory cytokines caused by DNA damage, causing cell transformations that can lead to tumor growth and induce chronic inflammation ${ }^{18,19}$. Relevant research shows that CRP levels in serum of patients with malignant tumors were significantly increased, and was closely correlated with the progress and prognosis of cancer. Studies on patients with colon cancer showed that tumor recurrence and staging were significantly correlated with CRP levels ${ }^{20-22}$.

The incidence of colorectal cancer is rising each year, and more than half of patients have metastases. The primary treatment for advanced colorectal cancer is chemotherapy, which can significantly improve patients' quality of life regarding better supportive care. For a long time, 5-fluorouracil has been a core drug in the treatment of gastrointestinal tumors. Its mechanism of action is similar to other platinum compounds. It forms DNA binding of platinum to ultimately inhibit DNA synthesis and DNA repair ${ }^{23-25}$. Compared to cisplatin, the rate of oxaliplatin binding with DNA in vivo is faster than over 10 times and their binding can be firmly combined, which has stronger cytotoxicity $^{26,27}$. A study by Jie et al. ${ }^{28}$ and other studies ${ }^{29,30}$ showed that oxaliplatin had an excellent therapeutic effect in the treatment of advanced gastrointestinal tumors and its cytotoxic effect was stronger without renal toxicity. In comparison with cisplatin, nausea and vomiting incidence of oxaliplatin was much lower, and hydration was not required. In addition, no severe hearing impairment and cardiac toxicity were found.

The baseline characteristics were observed before the therapy. Also, the responses to chemotherapy were evaluated after 4 courses. Therapeutic evaluation was conducted according to RECIST criteria [9], including complete remission(CP), partial response(PR), stable disease (SD) and progressive disease $(\mathrm{PD})$. The disease control rates $(\mathrm{DCR})=$ $\mathrm{CR}+\mathrm{PR}+\mathrm{SD}$, the objective response rate $(\mathrm{ORR})=$ $\mathrm{CR}+\mathrm{PR}$.

In summary, FOLFOX6 chemotherapy can decrease serum VEGF expression and the CRP level in patients with advanced colorectal cancer and enhance the curative effect with high safety which is good for the improvement of patients' quality of life. 


\section{RESUMO}

OBJETIVO: Explorar o efeito da quimioterapia Folfox6 na expressão do fator de crescimento endotelial vascular sérico (VEGF) em pacientes com câncer colorretal avançado.

MÉTODOS: Uma análise retrospectiva de 81 pacientes com câncer colorretal avançado que visitaram nosso hospital de março de 2014 a fevereiro de 2016 foi realizada. Todos os pacientes foram tratados com quimioterapia Folfox6. No dia 1, os doentes receberam oxaliplatina $100 \mathrm{mg} / \mathrm{m} 2 \mathrm{ivgtt}$ (2h), folinato de cálcio $200 \mathrm{mg} / \mathrm{m} 2 \mathrm{ivgtt}$ (2h), 5 fluorouracil $400 \mathrm{mg} / \mathrm{m} 2 \mathrm{iv}$ bolus e 5 fluorouracil $2.500 \mathrm{mg} /$ $\mathrm{m} 2$ ivgtt (5h). O curso de tratamento foi de duas semanas e foram necessários quatro cursos de tratamento. Foram observadas as alterações nos níveis de VEGF e CRP e qualidade de vida antes e após quatro cursos de quimioterapia e avaliados os efeitos terapêuticos e reações adversas após a quimioterapia.

RESULTADOS: Após o tratamento, a eficácia total da quimioterapia foi de 82,72\% (67/81), com 24 casos em remissão completa, 25 casos em resposta parcial, 18 casos em doença estável e 14 casos em doença progressiva. Os níveis de CRP e VEGF após o tratamento foram significativamente inferiores aos do tratamento $(5,69 \pm 0,77) \mathrm{mg} / \mathrm{L}$ vs. $(7,99 \pm 1,36) \mathrm{mg} / \mathrm{L} ;(443,26 \pm 21,55) \mathrm{pg} / \mathrm{mL}$ vs. $(542,83 \pm 20,44)$ $\mathrm{pg} / \mathrm{mL}](P<0,05)$. O grau de KPS após o tratamento foi significativamente maior do que antes do tratamento $(57,84 \pm 4,6$ pontos) vs. $(50,99 \pm 3,73$ pontos $)](P<0,05)$. Entre eles, três casos desenvolveram erupção cutânea, cinco casos sofreram perda de cabelo e nove casos desenvolveram náuseas e vômitos.

CONCLUSÃo: A quimioterapia Folfox6 pode, obviamente, diminuir a expressão de VEGF no soro em pacientes com câncer colorretal avançado e melhorar o efeito curativo com alta segurança, o que é bom para a melhoria da sobrevivência dos pacientes.

PALAVRAS-CHAVE: Neoplasias colorretais. Fator A de crescimento do endotélio vascular. Tratamento farmacológico.

\section{REFERENCES}

1. Yinna F. Analysis of expression levels of KLF4 and BIRC7 in colorectal cancer, adjacent tissues and adenoma, and their clinical significance. E-J Translational Med. 2016;3(4):61-3.

2. Wheeler SR, Shi C, Holt JA, Vnencak-Jones CL. Mutation profiles of synchronous colorectal cancers from a patient with Lynch syndrome suggest distinct oncogenic pathways. J Gastrointest Oncol. 2016;7(3):E64-71.

3. DeFilippis EM, Mehta M, Ludwig E. A potential association between exposure to hepatitis B virus and small bowel adenocarcinoma. J Gastrointest Oncol. 2016;7(3):495-8.

4. Aminisani N, Nikbakht HA, Hosseinei SR, Shamshirgaran SM. Adverse health behaviors among colorectal cancer survivors: a case study from Iran. J Gastrointest Oncol. 2016;7(3):373-9.

5. Silva GL, Moura EG, Bernardo WM, Leite de Castro V, Morais C, Baba ER, et al. Endoscopic versus surgical resection for early colorectal cancer: a systematic review and meta-analysis. | Gastrointest Oncol. 2016;7(3):32635.

6. Junwei F, Zhiyong Z, Aidong L. Expressios of MMP-7, VEGF-D and VEGFR-3 in colorectal carcinoma and its clinical significance. J Chongqing Medical University. 2012;37(3):205-8.

7. Zhiping $Y$, Huaping M, Qiu W. VEGF and sICAM-1 protein expressions and their clinical significance in serum of patients with colorectal cancer. I. Shandong University (Health Science). 2013;51(10):74-76, 80.

8. Kobayashi A, Morioka D, Matsumoto C, Miura Y1, Miura M1. Hepatocellular carcinoma incidentally detected at second hepatectomy for repeated colorectal liver metastasis in a patient with hepatitis $C$ virus-related cirrhosis: a case report. J Med Case Rep. 2016;10(1):136.

9. Xuening Y, Yilong W. RECIST-New guidelines to evaluate the response to treatment in solid tumors. | Evidence-based Medicine. 2004;4(2):85-30, 111.

10. Tanenbaum DG, Hall WA, Colbert LE, Bastien AJ, Brat DJ, Kong J, et al. TNFRSF10C copy number variation is associated with metastatic colorectal cancer. J Gastrointest Oncol. 2016;7(3):306-14.

11. Tomizawa M, Shinozaki F, Hasegawa R, Shirai Y, Motoyoshi Y, Sugiyama T, et al. Elevated C-reactive protein level predicts lower gastrointestinal tract bleeding. Biomed Rep. 2016;4(6):711-4.

12. Huiyong S, Zhongfa X. Research progression of chemotherapy to colorectal cancer. Chinese J Cancer Prev Treat. 2012;19(24):1915-8.

13. Xin S, Jianmin L, Ying J. K-ras gene mutation and expression of VEGF in colorectal cancer and their clinical significance. Chinese Clin Experim Pathol. 2013;29(3):330-2.
14. Fangfang D, Guohua $Y$, Jumin Z. Relationship and clinical significance of SPARC, MMP-2 and VEGF protein expression in colorectal cancer tissues. Chinese | Cancer Prev Treat. 2012;19(14):1086-90.

15. Xinze L. VEGF-targeted therapy for metastatic colorectal cancer and related biomarkers: recent advances. Chinese J General Surg. 2015;24(4):575-80.

16. Park WC, Kim HR, Kang DB, Ryu JS, Choi KH, Lee GO, et al. Comparative expression patterns and diagnostic efficacies of SR splicing factors and HNRNPA1 in gastric and colorectal cancer. BMC Cancer. 2016;16:358.

17. Wenbo N, Chaoxi Z, Juan Z. Impact of colorectal cancer laparoscopic and open surgery on immune function. Chinese J Immunol. 2015;31(5):670-3.

18. Li Z, Chencheng D, Fulin R. The diagnostic value of procalcitonin and high sensitivity $\mathrm{C}$-creative proteins for early postoperative inflammatory ileus of rectal cancer. J Practical Med. 2015;31(20):3398-400.

19. Kuo CT, Lee WS. Progesterone receptor activation is required for folic acid-induced anti-proliferation in colorectal cancer cell lines. Cancer Lett. 2016;378(2):104-10

20. Zilong C, Linlin R, Jingyou M. Relationship of IL-6, TNF- $\alpha$ and CRP with decrease of serum albumin in patients with advanced colorectal cancer. E-J Translational Med. 2015;2(5):76-8.

21. Truong A, Hanna MH, Moghadamyeghaneh Z, Stamos MJ. Implications of preoperative hypoalbuminemia in colorectal surgery. World | Gastrointest Surg. 2016;8(5):353-62.

22. Liangwei Y, Suping W, Li Z. Efficacy of dendritic cells/cytokine induced killer cells adoptive immunotherapy combined with chemotherapy in treatment of metastatic colorectal cancer. Chin J Cancer Biotherapy. 2013;20(2):217-24.

23. Junwei S, Pingping Z, Feng Z. Meta-analysis of prognosis of peri-operative chemotherapy for the treatment of resectable liver metastases from colorectal cancer. Chin J Cancer Prev Treat. 2015;22(6):474-8.

24. Tamura K, Hazama S, Yamaguchi R, Imoto S, Takenouchi H, Inoue $Y$, et al. Characterization of the $T$ cell repertoire by deep $T$ cell receptor sequencing in tissues and blood from patients with advanced colorectal cancer. Oncol Lett. 2016;11(6):3643-9.

25. Hong NY, Kim HR, Lee HM, Sohn DK, Kim KG. Fluorescent property of indocyanine green (ICG) rubber ring using LED and laser light sources. Biomed Opt Express. 2016,7(5):1637-44

26. Lee S, Shim JH, Gim H, Park HS, Kim B|. Ethanol extract of Oldenlandia diffusa - an effective chemotherapeutic for the treatment of colorectal cancer in humans: anti-cancer effects of Oldenlandia diffusa. I Pharmacopuncture. 2016;19(1):51-8. 
27. Yang Y, Duowu Z, Wei Z. A meta-analysis of cetuximab combined with chemotherapy in the treatment of advanced colorectal cancer. Chin I Cancer Biotherapy. 2012;19(3):303-8.

28. Jie G, Hai C, Suzhou P. Effect of immune function of CIK cells combined with DC cells adoptive immunotherapy in patients with colorectal cancer for chemotherapy. Chin J Modern Med. 2013;23(10):32-5.

29. Yang D, Li Y, Liu J, Jiang W, Ma D. Efficacy and tolerance of maintenance therapy in patients with incurable advanced colorectal cancer. Nan Fang Yi Ke Da Xue Xue Bao. 2013;33(12):1815-8.

30. Jinsong L, Liping L, Jun L. Impact of compound Kushen injection combined with chemotherapy on serum vascular endothelial growth factor in patients with advanced colorectal cancer. Chin J Gerontol. 2014;34(2):333-4.
31. Zhiwei Z. The development of the chemotherapy for colorectal cancer: a review of the 2001 ASCO meeting. Chin J Cancer. 2001;20(11):1322.

32. Gramont A, Figer A, Seymour M, Homerin M, Hmissi A, Cassidy J, et al. Leucovorin and fluorouracil with or without oxaliplatin as first-line treatment in advanced colorectal cancer. I Clin Oncol. 2000;18(16):2938-47.

33. Jungi M, Yinghui Z. Clinical efficiency of Oxaliplatin in the chemotherapy for advanced colorectal cancer. Modern Digestion Intervention. 2017;22(4):538-41.

34. Xiaoyan L, Sutang G. FOLFOX6 chemotherapy for advanced colorectal cancer. Chin Foreign Med Res. 2015;13(14):121-2. 